\title{
Rapid survey of bats (Chiroptera) in the Atlantic Forest in eastern Sergipe, Brazil: unexpected diversity in a fragmented landscape
}

\author{
Mônica A. Pedroso ${ }^{1}$, Arivania S. Pereira', Helon S. Oliveira ${ }^{1,2}$, \\ J. Weverton S. Souza ${ }^{1,6}$, Francis L.S. Caldas ${ }^{1,3}$, Raone Beltrão-Mendes ${ }^{1}$, \\ Juan Ruiz-Esparza ${ }^{4}$, Patrício A. Rocha ${ }^{5}$, Stephen F. Ferrari ${ }^{1}$
}

1 Post-Graduate Programme in Ecology and Conservation, Federal University of Sergipe, São Cristóvão, Brazil

2 Post-Graduate Programme in Biological Sciences, Department of Animal and Plant Biology, Center of Biological Sciences, Paraná State University at Londrina, CEP 86.057-970, Londrina, Paraná, Brazil

3 Department of Biology, Reptiles and Amphibians Laboratory, Federal University of Sergipe, São Cristóvão, Brazil

4 Nucleus of Education in Agrarian and Earth Sciences, Federal University of Sergipe, São Cristóvão, Brazil

5 Post-Graduate Programme in Biological Sciences (Zoology), Department of Systematics and Ecology, Federal University of Paraiba, University City, João Pessoa, 58051-900, Paraíba, Brazil

6 Post-Graduate Programme in Ecology, Department of Animal Biology, Institute of Biology, State University of Campinas, Cidade Universitária Zeferino Vaz, 13083-970 Campinas, São Paulo, Brazil

Corresponding author: Patrício A. Rocha (parocha2@yahoo.com.br)

Academic editor: A. M. Leal-Zanchet | Received 7 March 2020 | Accepted 14 July 2020 | Published 6 August 2020

Citation: Pedroso MA, Pereira AS, Oliveira HS, Souza JWS, Caldas FLS, Beltrão-Mendes R, Ruiz-Esparza J, Rocha PA, Ferrari SF (2020) Rapid survey of bats (Chiroptera) in the Atlantic Forest in eastern Sergipe, Brazil: unexpected diversity in a fragmented landscape. Neotropical Biology and Conservation 15(3): 317-331. https:// doi.org/10.3897/neotropical.15.e51821

\begin{abstract}
Despite advances in recent decades, the Atlantic Forest of northeastern Brazil is still one of the least studied regions of the country, regarding, for instance, the bat fauna. The present study reports on the results of a rapid survey of the bat fauna of a fragmented landscape in the Atlantic Forest of eastern Sergipe, in the legal forest reserve of Fazenda Santana, a commercial sugarcane plantation located in the adjoining municipalities of Japoatã and Pacatuba. We recorded 272 bats belonging to 23 species and four families, from which 265 individuals from 18 species from two families (Phyllostomidae and Vespertilionidae) were captured in the mist-nets, and seven individuals of six species from four families (Emballonuridae, Molossidae, Phyllostomidae and Vespertilionidae) were recorded during the active searches. This species richness was higher than that found in previous studies in the Atlantic Forest of northeastern Brazil. Lasiurus blossevillii and Micronycteris minuta
\end{abstract}


were recorded in Sergipe for the first time, increasing to 57 the number of bat species known to occur in this state. The use of alternative strategies (such as active search and sampling one night per point, seeking to areas with greater availability of resources) in rapid surveys may contribute to the compilation of a more robust sampling, reinforcing the usefulness of this approach for the inventory of the bat fauna of a given region.

\section{Keywords}

Lasiurus blossevillii, Micronycteris minuta, new records, sugarcane

\section{Introduction}

The Brazilian Atlantic Forest is a biodiversity hotspot, considered to be one of the world's most threatened biomes (Mittermeier et al. 2004; Varjabedian 2010). This biome initially covered an area of well over a million square kilometers (Muylaert et al. 2018). The reduction of its original cover to among 11-16\% (in different regions) (Ribeiro et al. 2009) resulted in the ongoing loss of innumerable plant and animal species, including many endemic taxa (Paglia et al. 2012; ICMBio 2018). The northern extreme of the Biome (up to $15^{\circ} \mathrm{S}$ ), which encompasses the Northeastern region of Brazil, has suffered the highest rates of deforestation and habitat fragmentation (IBGE 2016).

Additionally, the Atlantic forest of Northeast Brazil is still one of the least studied areas of the country (Bernard et al. 2011). Despite advances in recent decades, the lack of knowledge concerning the real patterns of diversity and distribution of some taxa, such as the bat fauna (e.g., Falcão et al. 2005; Mikalauskas 2005; Faria et al. 2006; Percequillo et al. 2007; Rocha et al. 2010; Brito and Bocchiglieri 2012), partially results in the underestimation of the current damage in the diversity caused by land-use change and native habitats degradation.

In the Atlantic forest, bats (Chiroptera) are the second most diverse mammalian order after Rodentia (Reis et al. 2007). Up to now, 182 bat species have been recorded in Brazil, representing 69 genera in nine families (Nogueira et al. 2018), which makes Brazil the second country with the most diverse bat fauna in the Neotropical region (Díaz et al. 2016). From those, approximately 117 species are known to occur in the Atlantic forest (Varzinczak et al. 2015). Bats are considered to play an important role in the ecology of forests, in particular as pollinators and seed dispersers (Lobova et al. 2009; Peracchi et al. 2011). They are fundamentally important for the regeneration of degraded areas (Dumont 2003; Bredt et al. 2012). Some species are also sensitive to habitat disturbance (Aguirre et al. 2003), making them useful as indicators of environmental quality (Fenton et al. 1992; Jones et al. 2009).

In Sergipe, northeastern Brazil, less than $10 \%$ of its original Atlantic forest cover remains standing (Santos et al. 2013; Marques et al. 2017). Up to now, 55 bat species have been recorded in the state (see Bocchiglieri and Bezerra 2018; Rocha et al. 2017a, b, 2018; Soares et al. 2017). However, many areas have yet to be surveyed adequately, preferentially using combined methods already known 
to be complementary, such as stratified or canopy mist-nets (see Pech-Canche et al. 2011), ultrasound acoustics (see Silva and Bernard 2017), and active search for diurnal shelters (see Simmons and Voss 1998).

Despite the high difference in the sampling effort among studies that aim to inventory bat species richness and composition in each study site, the majority of the available studies have used mist-netting in monthly samples along the year (see Muylaert et al. 2017). Longitudinal inventories require a larger investment of human effort, finance, and logistics, commonly being executed in Protected Areas, since these areas usually offer some support (eg., lodgings, laboratories and drinking water). Conversely, rapid inventories (widely applied in environmental licensing in Brazil) are designed to sample a great data volume, as large as possible, in a short time interval, rarely higher than two weeks (PA Rocha, pers. comm.). When well-executed, therefore, rapid surveys are reliable to survey and inventory the richness and composition of bat species in a landscape at a much lower cost, mainly when using complementary sampling methods. Here we report the results of a rapid survey of the bat fauna of a fragmented landscape surrounded by a sugarcane plantation in the Atlantic forest of eastern Sergipe. In addition, we present the first record for the state of Sergipe for two bat species, highlighting the importance of surveying new sites even in rapid inventories.

\section{Material and methods}

\section{Study area}

The present study was conducted in the legal forest reserve of Fazenda Santana (600 ha of forest fragments; $10^{\circ} 32^{\prime} 07^{\prime \prime S}, 36^{\circ} 45^{\prime} 54^{\prime \prime} \mathrm{W}$ ), a sugarcane plant and farm located along the municipalities of Japoatã and Pacatuba, state of Sergipe (Fig. 1). The study area is a mosaic mainly composed of seasonal semideciduous Atlantic forest fragments, mainly represented by primary and secondary stages, with a small portion of riparian forest, complemented by enclaves of Restinga (Farias 2013; Authors pers. obs.). The fragments are set within a matrix of a large commercial plantation of sugarcane (Saccharum sp.) on an industrial scale. According to Köppen's classification, the local climate is As (Kottek et al. 2006; Alvares et al. 2013): Tropical Megathermal with a dry season in the summer. The annual rainfall ranges between 1,000 and $1,400 \mathrm{~mm}$, with an average temperature between $22.7^{\circ} \mathrm{C}$ and $26.5^{\circ} \mathrm{C}$ (Aragão et al. 2013).

\section{Data collection}

We conducted the samplings over 10 consecutive nights, between October $19^{\text {th }}$ to $28^{\text {th }}, 2016$. The bats were captured using mist-nets ( 12 nets of $12 \mathrm{~m} \times 3 \mathrm{~m}$; totaling $144 \mathrm{~m}$ on each transect) set at ground level, which we translocated at the end of each sampling night to cover eight transects established in different fragments of 
the semideciduous seasonal forest within the mosaic (Fig. 1). During each sampling night, we opened the mist-nets from 18:00 h to 00:00 h, checking every 30 minutes. Captured bats were placed in cloth bags, and subsequently still in the field were identified according to Gardner (2007) and Díaz et al. (2016).

Complementarily, we conducted nonsystematic samplings through active searches during the daytime, investigating existing trails looking for feeding perches, possible natural shelters (dead trees, and tree holes), and human-made constructions (mainly abandoned buildings) within the Fazenda Santana. Eventually, natural shelters were opportunistically found by the research team during live trapping reviewing for small mammals. Whenever we found the shelters, we captured the bats using a net-gear trap (puçá), and/or a mist-net section positioning them in the opening of the shelters, as well as capturing the animals with the aid of a large tweezer when animals were confined in small spaces, such as between roof tiles. We collected voucher specimens of each sampled species (by systematic or nonsystematic samplings) that we deposited in the mammalian collection of the Laboratory of Conservation Biology (LBC) of the Federal University of Sergipe in São Cristóvão, Brazil (Appendix I). Specimens were collected under the permit SISBIO 7034-1.

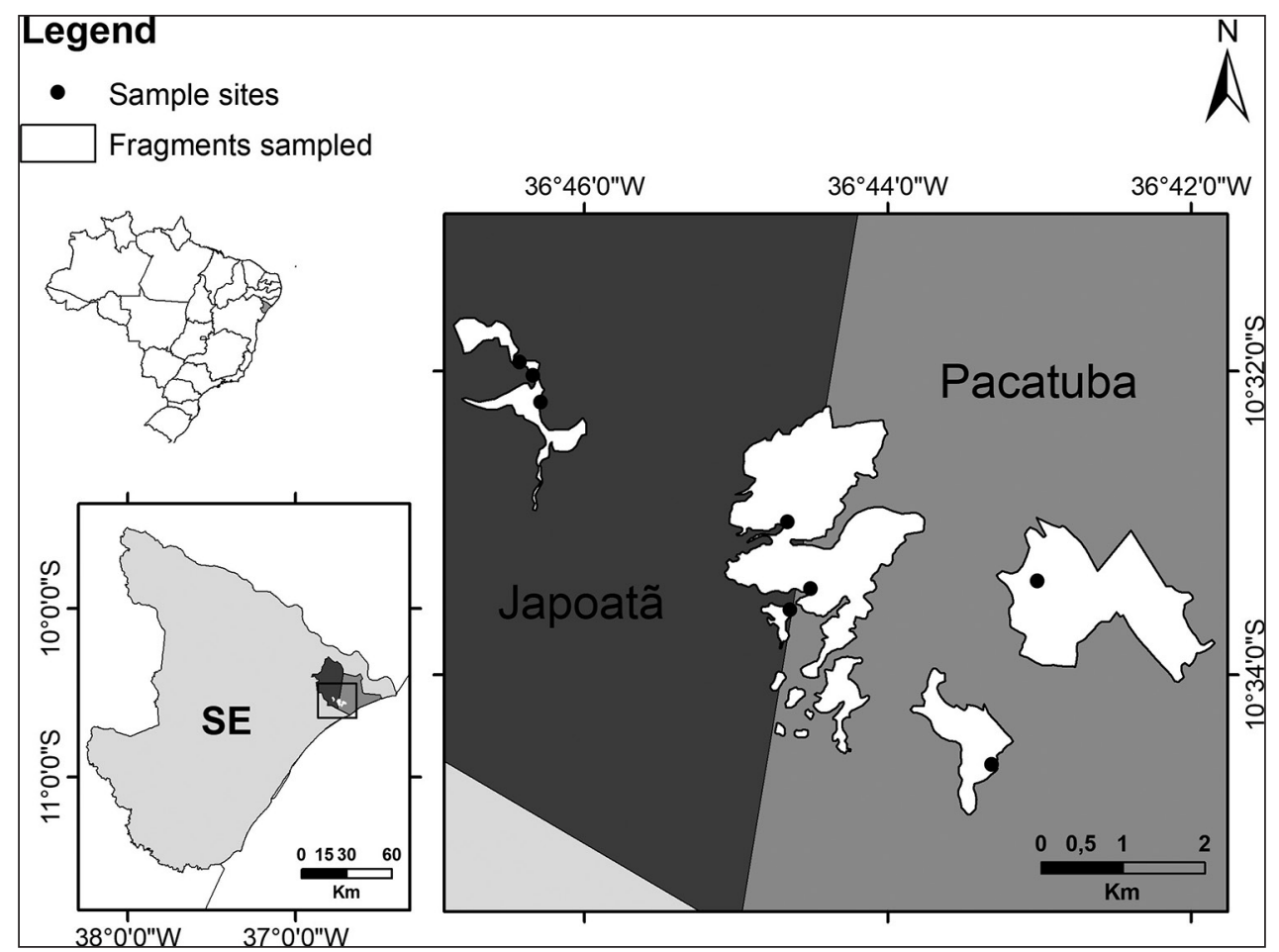

Figure 1. Sampling sites at which bats were collected in mist-nets in the fragments of Atlantic forest on Fazenda Santana, owned by the Brazilian Alcohol and Sugar Company (CBAA), in the municipalities of Pacatuba and Japoatã in Sergipe, northeastern Brazil. 


\section{Data analysis}

The nomenclature we adopted followed Nogueira et al. (2018). We calculated the sampling effort according to Straube and Bianconi (2002), while the species richness was based on the estimator Jackknife 1, and calculated on EstimateS 9.0 (Colwell 2005) based on 1,000 iterations (see Colwell and Coddington 1994). At last, all the species were classified by their feeding guild, as defined by Kalko et al. (1996), with six trophic guilds being considered, namely frugivore, insectivore, omnivore, nectarivore, carnivore, and hematophagous. Sampling effort and species richness were run only to systematically sampled data, while the species recorded during the active searches were considered only to the species inventory and listing.

\section{Results}

After $25,920 \mathrm{~h} / \mathrm{m}^{2}$ of mist-netting sampling effort, we captured 265 individuals belonging to 18 species from two families (Phyllostomidae and Vespertilionidae). (Table 1; Fig. 2). Through the complementary active search, we sampled an additional seven individuals belonging to six species from four families (Emballonuridae, Molossidae, Phyllostomidae and Vespertilionidae) (Table 1; Fig. 3). Five species from two families were recorded only by active searches, representing $21.7 \%$ of the total richness, 23 species (Fig. 3). Through the systematic mist-netting, we sampled ap-

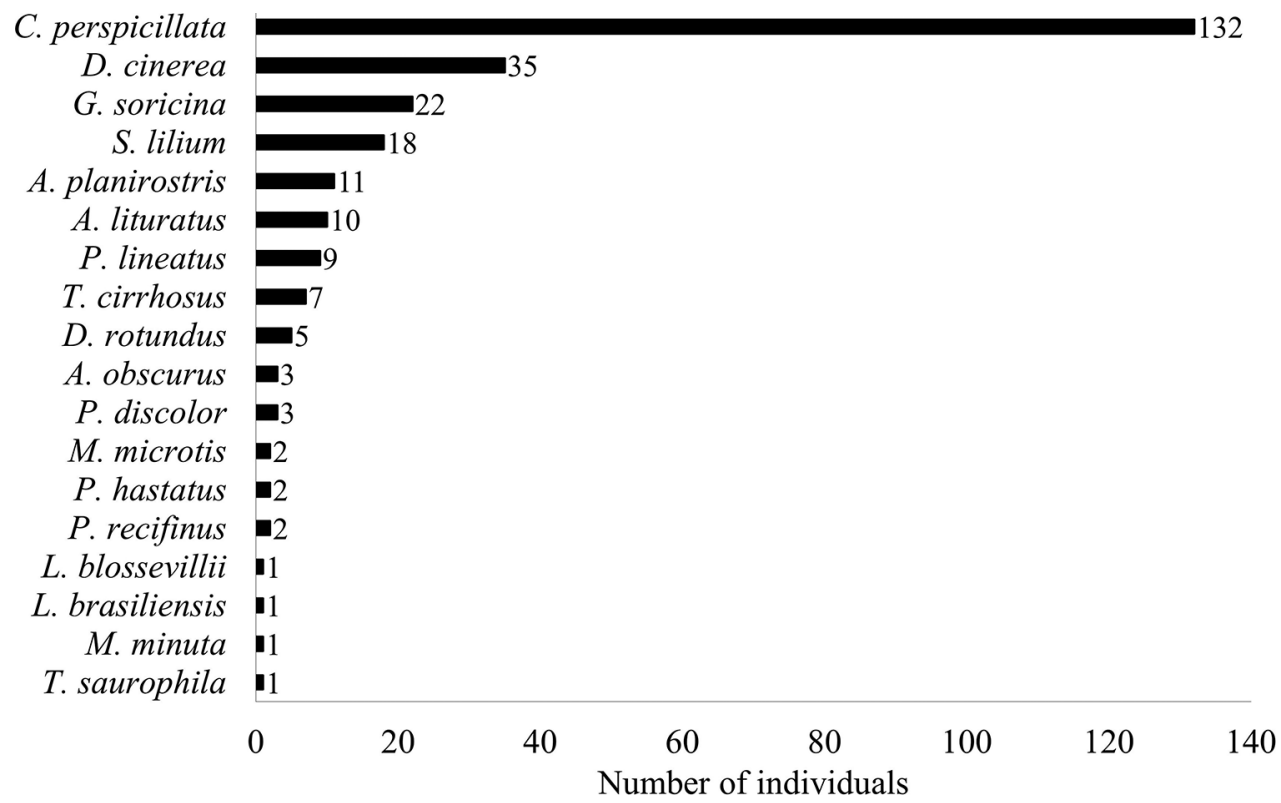

Figure 2. Relative abundance of each bat species recorded (using mist-nets) in the fragments of Atlantic forest on Fazenda Santana, in the municipalities of Pacatuba and Japoatã in Sergipe, northeastern Brazil. 
Table 1. Bat species recorded in the in the fragments of Atlantic Forest on Usina Santana, owned by the Brazilian Alcohol and Sugar Company (CBAA), in the municipalities of Pacatuba and Japoatã in Sergipe, northeastern Brazil; abundance and trophic guilds; ${ }^{*}$ - New record for the Brazilian state of Sergipe. A/S: Active Searches; M/N: Mist-Netting; Net's (\%): Relative Abundance in mist-nets.

\begin{tabular}{|c|c|c|c|c|}
\hline \multirow[t]{2}{*}{ Taxon } & \multicolumn{2}{|c|}{ Number of individuals } & \multirow[t]{2}{*}{ Net's (\%) } & \multirow[t]{2}{*}{ Guild } \\
\hline & $\mathrm{A} / \mathrm{S}$ & $\mathbf{M} / \mathbf{N}$ & & \\
\hline \multicolumn{5}{|l|}{ Emballonuridae } \\
\hline \multicolumn{5}{|l|}{ Emballonurinae } \\
\hline Peropteryx leucoptera Peters, 1867 & 2 & & & Insectivorous \\
\hline Peropteryx macrotis (Wagner, 1843) & 1 & & & Insectivorous \\
\hline \multicolumn{5}{|l|}{ Molossidae } \\
\hline \multicolumn{5}{|l|}{ Molossinae } \\
\hline Molossus molossus (Pallas, 1766) & 1 & & & Insectivorous \\
\hline \multicolumn{5}{|l|}{ Phyllostomidae } \\
\hline \multicolumn{5}{|l|}{ Phyllostominae } \\
\hline Lophostoma brasiliense (Peters, 1866) & & 1 & $0.4 \%$ & Insectivorous \\
\hline Phyllostomus discolor Wagner, 1843 & & 3 & $1.1 \%$ & Omnivorous \\
\hline Phyllostomus hastatus (Pallas, 1767) & & 2 & $0.8 \%$ & Omnivorous \\
\hline Tonatia saurophila Koopman \& Williams, 1951 & & 1 & $0.4 \%$ & Insectivorous \\
\hline Trachops cirrhosus (Spix, 1823) & & 7 & $2.6 \%$ & Carnivorous \\
\hline \multicolumn{5}{|l|}{ Carolliinae } \\
\hline Carollia perspicillata (Linnaeus, 1758) & & 132 & $49.8 \%$ & Frugivorous \\
\hline \multicolumn{5}{|l|}{ Desmodontinae } \\
\hline Desmodus rotundus (É. Geoffoy, 1810) & & 5 & $1.9 \%$ & Hematophagous \\
\hline \multicolumn{5}{|l|}{ Glossophaginae } \\
\hline Glossophaga soricina (Pallas, 1766) & 1 & 22 & $8.3 \%$ & Nectarivorous \\
\hline \multicolumn{5}{|l|}{ Micronycterinae } \\
\hline Micronycteris microtis Miller, 1898 & & 2 & $0.8 \%$ & Insectivorous \\
\hline Micronycteris minuta (Gervais, 1856)* & & 1 & $0.4 \%$ & Insectivorous \\
\hline \multicolumn{5}{|l|}{ Stenodermatinae } \\
\hline Artibeus lituratus (Olfers, 1818) & & 10 & $3.8 \%$ & Frugivorous \\
\hline Artibeus obscurus Schinz, 1821 & & 3 & $1.1 \%$ & Frugivorous \\
\hline Artibeus planirostris (Spix, 1823) & & 11 & $4.2 \%$ & Frugivorous \\
\hline Dermanura cinerea Gervais, 1856 & & 35 & $13.2 \%$ & Frugivorous \\
\hline Platyrrhinus lineatus (É. Geoffoy, 1810) & & 9 & $3.4 \%$ & Frugivorous \\
\hline Platyrrhinus recifinus (Thomas, 1901) & & 2 & $0.8 \%$ & Frugivorous \\
\hline Sturnira lilium (É. Geoffoy, 1810) & & 18 & $6.8 \%$ & Frugivorous \\
\hline \multicolumn{5}{|l|}{ Vespertilionidae } \\
\hline \multicolumn{5}{|l|}{ Vespertilioninae } \\
\hline Myotis lavali Moratelli, Peracchi, Dias \& Oliveira, 2011 & 1 & & & Insectivorous \\
\hline Myotis riparius Handley, 1960 & 1 & & & Insectivorous \\
\hline Lasiurus blossevillii (Lesson \& Garnot, 1826)* & & 1 & $0.4 \%$ & Insectivorous \\
\hline Total & 7 & 265 & $100 \%$ & \\
\hline
\end{tabular}

proximately $77 \%(S=18)$ of the estimated richness $(S=23.4 \pm 1.99)$, considered as significantly different according to the Jackknife 1 estimator (Fig. 4).

Through the mist-netting, specimens of the family Phyllostomidae were the most captured $(\mathrm{N}=264 ; 99.6 \%)$, with also the higher number of species ( $\mathrm{S}=17$; $94.4 \%$ ), and a single vespertilionid species (Lasiurus blossevillii) being captured. Among the phyllostomids, the Stenodermatinae was the subfamily with the high- 


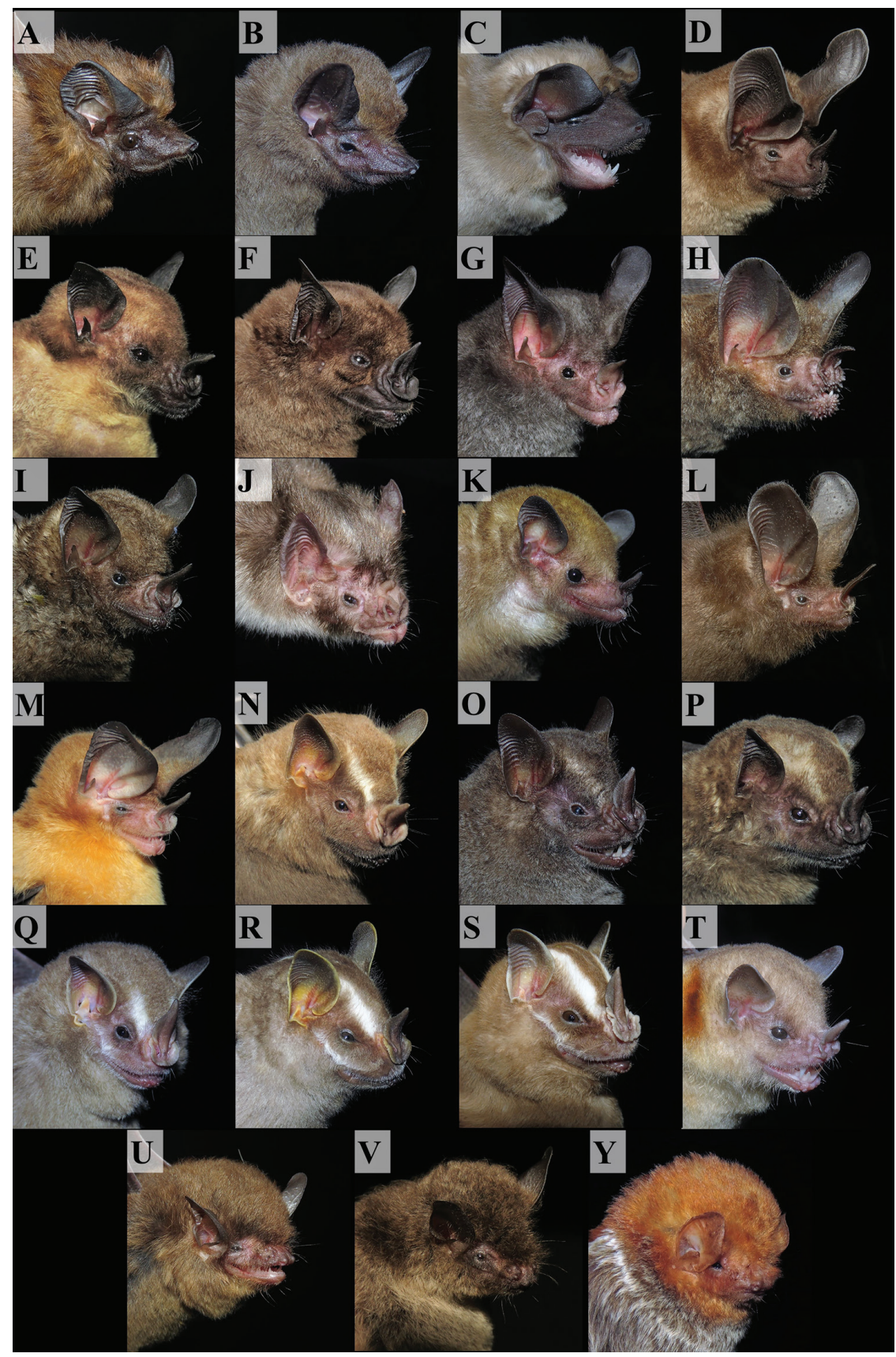

Figure 3. Bat species recorded in the fragments of Atlantic forest on Usina Santana, owned by the Brazilian Alcohol and Sugar Company (CBAA), in the municipalities of Pacatuba and Japoatã in Sergipe, northeastern Brazil. A Peropteryx leucoptera; B Peropteryx macrotis; C Molossus molossus; D Lophostoma brasiliense; E Phyllostomus discolor; F Phyllostomus hastatus; G Tonatia saurophila; H Trachops cirrhosus; I Carollia perspicillata; J Desmodus rotundus; L Glossophaga soricina; $\mathbf{M}$ Micronycteris microtis; $\mathbf{N}$ Micronycteris minuta; O Artibeus lituratus; $\mathbf{P}$ Artibeus obscurus; $\mathbf{Q}$ Artibeus planirostris; $\mathbf{R}$ Dermanura cinerea; $\mathbf{S}$ Platyrrhinus lineatus; T Platyrrhinus recifinus; $\mathbf{U}$ Sturnira lilium; V Myotis lavali; X Myotis riparius; $\mathbf{Y}$ Lasiurus blossevillii. 


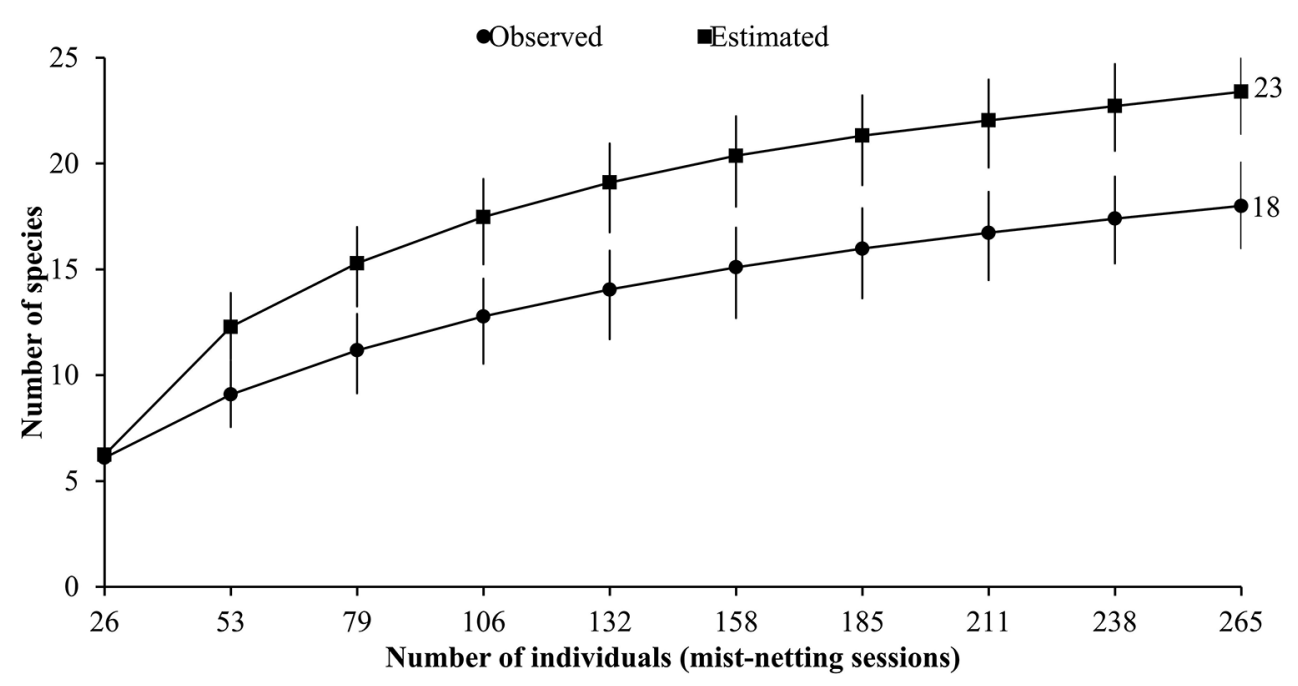

Figure 4. Observed and estimated (Jackknife 1) bat species richness in the fragments of Atlantic forest on Fazenda Santana, owned by the Brazilian Alcohol and Sugar Company (CBAA), in the municipalities of Pacatuba and Japoatã in Sergipe, northeastern Brazil.

est species richness, with seven species from four genera, while Carolliinae was the subfamily with the highest abundance, with 132 individuals of Carollia perspicillata (Linnaeus, 1758), representing half of all the individuals sampled by mistnetting. The five other most abundant species were Dermanura cinerea Gervais, $1856(\mathrm{n}=35 ; 12.9 \%$ of the total), Glossophaga soricina (Pallas, 1766$)(\mathrm{n}=22 ; 8.3 \%)$, Sturnira lilium (É. Geoffoy, 1810) $(\mathrm{n}=18 ; 6.8 \%)$, Artibeus planirostris (Spix, 1823) $(\mathrm{n}=11 ; 4.2 \%)$, and Artibeus lituratus (Olfers, 1818) $(\mathrm{n}=10 ; 3.8 \%)$. The remaining species (see Table 1 and Fig. 2 for details) were relatively rare, with no more than nine individuals. The capturing of Lasiurus blossevillii (Lesson \& Garnot, 1826), and Micronycteris minuta (Gervais, 1856) represent the first records in the Brazilian state of Sergipe.

The emballonurids Peropteryx leucoptera Peters, 1867, and Peropteryx macrotis (Wagner, 1843), the molossid Molossus molossus (Pallas, 1766), and the vespertilionids Myotis lavali Moratelli, Peracchi, Dias \& Oliveira, 2011 and Myotis riparius Handley, 1960 were recorded only during active searches. Peropteryx leucoptera Peters, 1867 was captured by encountering its natural shelter in the middle of the forest, consisting of a crevice covered by a tangle of dead branches near the roots of a tree, on the lateral of a dry ravine. All the other species recorded during active searches were found in anthropogenic shelters (buildings).

Regarding the trophic guilds, the frugivores constituted the feeding guild with the highest species richness, $(S=8 ; 44.4 \%$ of the total), followed by insectivores $(S=5$; $28.8 \%$ ), and omnivores ( $\mathrm{S}=2 ; 11.1 \%$ ). The carnivorous, nectarivorous, and hematophagous guilds were represented by a single species each. Frugivores were also more abundant, with 219 individuals being captured (83.0\% of the total), followed by the nectarivores, with 22 individuals (8.3\%), all representing a single species, G. soricina. 


\section{Discussion}

The species richness recorded in the present study $(S=23)$ was higher than those found in previous studies in the Atlantic forest from northeastern Brazil, which recorded 13 (Falcão et al. 2005), 14 (Brito and Bocchiglieri 2012), 16 (both Mikalauskas 2005 and Rocha et al. 2017a), and 18 species (Rocha et al. 2010). The sampling effort applied during the present study may not be considered satisfactory, given that the cumulative species curve had yet to reach the asymptote. It is interesting to note, however, that the estimated species richness was similar to that recorded in the present study adding mist-nets and active search (i.e., 23 species). Nonetheless, the relatively large number of species recorded is the result of combined sampling strategies, such as the nightly change in transect and the sampling of different habitats as much as possible (see Rocha et al. 2017a).

The most frequent species in the present study are from the family Phyllostomidae, which are the predominant and most abundant species in the majority of the bat inventories in the Atlantic forest using mist-netting (see Muylaert et al. 2017), reflecting the selective nature of this method (Gardner 2007; Peracchi et al. 2011). In particular, vespertilionids, molossids and emballonurids have a well-developed echolocation system, which helps them to detect and avoid mist-nets (Fenton et al. 1992). In this sense, complementing the mist-netting, the use of ultrasound detectors is essential to access the richness of non-phyllostomid bats (Silva and Bernard 2017), providing a better understanding of the chiropterofauna of a landscape.

Two of the species recorded here, L. blossevillii and M. minuta, were recorded in Sergipe for the first time. The Southern Red Bat, L. blossevillii, is found throughout tropical South America, except Chile, most of Central America, and the western United States (Simmons 2005; Gardner 2007). The species is widely distributed in Brazil, where it has been recorded in 14 different states (Gardner 2007; Tavares et al. 2008), including Ceará (Piccinini 1974; Willig 1983), Alagoas (Sousa et al. 2004), Pernambuco (Sousa et al. 2004) and Paraíba (Dias et al. 2010), all located in the Northeast Region. The record from Sergipe is the first one within a gap of $1,100 \mathrm{~km}$ in the Atlantic Forest, between the records from the southern states of Alagoas (Sousa et al. 2004) and Espírito Santo (Ruschi 1954).

Micronycteris minuta is also found in Central and South America (Gardner 2007). In northeastern Brazil, it has been recorded in the states of Ceará (Willig 1983), Piauí (Araújo et al. 1998), Pernambuco (Guerra 2007; Marinho-Filho and Reis 2007; Astúa and Guerra 2008; Silva and Marinho-Filho 2010; Leal et al. 2013a), Maranhão (Dias et al. 2007, 2009), Paraíba (Dias et al. 2010; Feijó and Langguth 2011; Leal et al. 2013b), and Bahia (Faria et al. 2006). The present record from Sergipe state falls within a gap of $700 \mathrm{~km}$ between southern Bahia and Pernambuco states. The species appears to be relatively common in disturbed forest and crop plantations, as in the present study area (Peracchi and Albuquerque 1993; Bernard and Fenton 2002; Sampaio et al. 2003).

The active searches conducted during the present study provided important complementary data, including species from two families (Emballonuridae and Molossidae) not recorded in the mist-nets. One of the species recorded during these 
searches, $P$. leucoptera, is extremely rare in the Atlantic forest. The present record is only the fifth for the biome, and the second outside the Pernambuco Endemism Center (see Mikalauskas et al. 2014). Positioning mist-nets along different transects on consecutive nights was proposed by Larsen et al. (2007) and Marques et al. (2013). According to these authors, this strategy increases the sampling efficiency, given that bats can learn to identify and avoid the nets, and this could explain the richness in the present study. In this sense, using an expressive sampling effort in Amazon rainforest, Pedroso (2018) concludes that there is a significant decrease in the success of capturing mist-nets armed by consecutive nights in the same place. Shifting the position of the nets also contributes to the sampling of a greater number of microhabitats within a given study area (Esbérard 2006).

The present study indicated that the use of alternative sampling strategies in rapid surveys contribute to the compilation of a more robust inventory, reinforcing the usefulness of this approach for the understanding of the bat fauna of a given region. In addition, this study increased to 57 the number of bat species known to occur in the Brazilian state of Sergipe.

\section{Acknowledgments}

We thank the Coordenação de Aperfeiçoamento de Pessoal de Nível Superior (CAPES) for the MSc stipends to MAP, ASP, HSO, JWSS, and for the post-doctoral fellowships to RB-M (88887.320996/2019-00) and PAR (88882.317933/2019-01). We also thank the Conselho Nacional de Desenvolvimento Científico e Tecnológico (CNPq) for the post-doctoral financial support to FLSC (150827/2018-0). RB-M was also supported by The Mohamed bin Zayed Species Conservation Fund (Project 12055114), Primate Action Fund (Project 1001257), and Primate Conservation Inc. (Project 1158). We thanks the Instituto Chico Mendes de Conservação da Biodiversidade (ICMBio) for the research license (SISBio: 7034-1). We are also grateful to the staff of Fazenda Santana for providing the support and infrastructure necessary for the present study, and to James Cardozo for his excellent field assistance.

\section{References}

Aguirre LF, Lens L, Van Dame R, Matthysen E (2003) Consistency and variation in the bat assemblages inhabiting two forest islands within a Neotropical Savana in Bolivia. Journal of Tropical Ecology 19(4): 367-374. https://doi.org/10.1017/S0266467403003419

Alvares CA, Stape JL, Sentelhas PC, Gonçalves JLM, Sparovek G (2013) Köppen’s climate classification map for Brazil. Meteorologische Zeitschrift 22(6): 711-728. https://doi. org/10.1127/0941-2948/2013/0507

Aragão R, Santana GR, Costa CEFF, Cruz MA, Figueiredo EE, Srinivasan VS (2013) Chuvas intensas para o estado de Sergipe com base em dados desagregados de chuva diária. Revista Brasileira de Engenharia Agrícola e Ambiental 17(3): 243-252. https://doi. org/10.1590/S1415-43662013000300001

Araújo AJG, Pessis AM, Guérin C, Dias CMM, Alves C, Salvia ES, Olmos F, Parenti F, Felice GD, Pellerin J, Emperaire L, Chame M, Lage MCSM, Faure M, Guidon N, Me- 
deiros RP, Simões PRG (1998) Parque Nacional Serra da Capivara. Fundham, São Raimundo Nonato, 94 pp.

Astúa D, Guerra DQ (2008) Caatinga bats in the Mammal Collection of the Universidade Federal de Pernambuco. Chiroptera Neotropical 14(1): 326-338.

Bernard E, Aguiar LM, Machado RB (2011) Discovering the Brazilian bat fauna: A task for two centuries? Mammal Review 41(1):23-39.https://doi.org/10.1111/j.1365-2907.2010.00164.x

Bernard E, Fenton MB (2002) Species diversity of bats (Mammalia: Chiroptera) in forest fragments, primary forests, and savannas in central Amazonia, Brazil. Canadian Journal of Zoology 80(6): 1124-1140. https://doi.org/10.1139/z02-094

Bocchiglieri A, Bezerra RH (2018) First record of Myotis riparius Handley, 1960 (Chiroptera, Vespertilionidae) in Sergipe, northeastern Brazil. Check List 14(5): 817-821. https://doi.org/10.15560/14.5.817

Bredt A, Uieda W, Pedro WA (2012) Plantas e Morcegos, na recuperação de áreas degradadas e na paisagem urbana. Rede de Sementes do Cerrado, Brasília, 276 pp.

Brito DV, Bocchiglieri A (2012) Comunidades de morcegos (Mammalia, Chiroptera) no Refúgio de Vida Silvestre Mata do Junco, Sergipe, nordeste do Brasil. Biota Neotropica 12(3): 1-9. https://doi.org/10.1590/S1676-06032012000300025

Colwell RK (2005) EstimateS: statistical estimation of species richness and shared species from samples. [Version 8 User's Guide and application published at] http://purl.oclc.org/estimates

Colwell RK, Coddington JA (1994) Estimating terrestrial biodiversity through extrapolation. Philosophical Transactions of the Royal Society 345(1311): 101-118. https://doi. org/10.1098/rstb.1994.0091

Dias PA, Almeida RB, Oliveira TG (2007) Quiropterofauna associada à floresta de mangue no estado do Maranhão, Brasil. In: Rosso S (Ed.) Anais do VIII Congresso de Ecologia do Brasil. VIII Congresso de Ecologia do Brasil, Caxambú (Brasil), September 2007. Sociedade de Ecologia do Brasil, São Paulo, 1-2.

Dias D, Pereira SN, Maas ACS, Martins MA, Bolzan DP, Peracchi AL (2010) Quirópteros das regiões Centro-Sul e Médio Paraíba do estado do Rio de Janeiro (Mammalia, Chiroptera). Chiroptera Neotropical 16(1): 579-585.

Dias PA, Santos CLC, Rodrigues FS, Rosa LC, Lobato KS, Rebêlo JMM (2009) Espécies de moscas ectoparasitas (Diptera, Hippoboscoidea) de morcegos (Mammalia, Chiroptera) no estado do Maranhão. Revista Brasileira de Entomologia 53(1): 128-133. https://doi.org/10.1590/S0085-56262009000100027

Díaz MM, Solari S, Aguirre LF, Aguiar LMS, Barquez RB (2016) Clave de identificación de los murciélagos de sudamérica ( $1^{a}$ edición). Publicación especial n 2 , PCMA (Programa de Conservación de Los Murciélagos de Argentina), Tucumán, 160 pp.

Dumont ER (2003) Bats and fruit: an ecomorphological approach. In: Kunz TH, Fenton MB (Eds) Bat Ecology. The University of Chicago, Chicago, 398-429.

Esbérard CEL (2006) Efeito da coleta de morcegos por noites seguidas no mesmo local. Revista Brasileira deZoologia23(4): 1093-1096. https://doi.org/10.1590/S0101-81752006000400016

Falcão FC, Soares-Santos B, Drummond S (2005) Espécies de morcegos do Planalto da Conquista, Bahia, Brasil. Chiroptera Neotropical 11(1-2): 220-223.

Faria D, Soares-Santos B, Sampaio E (2006) Bats from the Atlantic rainforest of southern Bahia, Brazil. Biota Neotropica 6(2): 1-13. https://doi.org/10.1590/S1676-06032006000200022 
Farias MCV (2013) Apresentando Sergipe. In: Prata APN, Amaral MCE, Farias MCV, Alves MV (Eds) Flora de Sergipe, v.1. Gráfica e Editora Triunfo, Aracaju, 19-34.

Feijó JA, Langguth A (2011) Lista de quirópteros da Paraíba, Brasil com 25 novos registros. Chiroptera Neotropical 17(2): 1052-1066.

Fenton MB, Acharya L, Audet D, Hickey MBC, Merriman C, Obrist MK, Syme DM, Adkins B (1992) Phyllostomid bats (Chiroptera: Phyllostomidae) as indicators of habitat disruption in the Neotropics. Biotropica 24(3): 440-446. https://doi.org/10.2307/2388615

Gardner AL (2007) Mammals of South America, Marsupials, Xenarthrans, Shrews, and Bats.

Volume 1. In: Gardner AL (Ed.) Order Chiroptera. The University of Chicago Press, Chicago and London, 187-481. https://doi.org/10.7208/chicago/9780226282428.001.0001

Guerra DQ (2007) Chiroptera de Pernambuco: distribuição e aspectos biológicos. Master Dissertation, Universidade Federal de Pernambuco, Recife, 103 pp.

IBGE [Instituto Brasileiro de Geografia e Estatística] (2016). Cidades. http://cidades.ibge. gov.br/xtras/uf.php?coduf=28 [acessed on: 16/10/2016]

ICMBio [Instituto Chico Mendes de Conservação da Biodiversidade] (2018) Livro Vermelho da Fauna Brasileira Ameaçada de Extinção: Volume II - Mamíferos. In: Instituto Chico Mendes de Conservação da Biodiversidade (Ed.) Livro Vermelho da Fauna Brasileira Ameaçada de Extinção. ICMBio, Brasília, 622 pp.

Jones G, Jacobs DS, Kunz TH, Willig MR, Racey PA (2009) Carpe noctem: The importance of bats as bioindicators. Endangered Species Research 8: 93-115. https://doi. org/10.3354/esr00182

Kalko EKV, Handley CO, Handley D (1996) Organization, diversity, and long-term dynamics of a Neotropical bat community. In: Cody ML, Smallwood JA (Eds) Longterm studies of vertebrate communities. Academic Press, Los Angeles, 503-553. https://doi.org/10.1016/B978-012178075-3/50017-9

Kottek M, Grieser J, Beck C, Rudolf B, Rubel F (2006) World Map of the Köppen-Geiger climate classification updated. Meteorologische Zeitschrift 15(3): 259-263. https://doi. org/10.1127/0941-2948/2006/0130

Larsen RJ, Boegler KA, Genoways HH, Masefield WP, Kirsch RA, Pedersen SC (2007) Mist netting bias, species accumulation curves, and the rediscovery of two bats on Montserrat (Lesser Antilles). Acta Chiropterologica 9(2): 423-435. https://doi.org/10.3161/17335329(2007)9[423:MNBSAC]2.0.CO;2

Leal ESB, Ramalho DF, Miller BG, Filho SAM, Araújo VML, Siva LAMS, Guerra DQ (2013a) Inventário da quiropterofauna (Mammalia: Chiroptera) do campus da Universidade Federal de Pernambuco, nordeste do Brasil. Boletim do Museu de Biologia Mello Leitão 32: 53-70.

Leal ESB, Ramalho DF, Silva DQ, Miller BG, Carvalho PJB, Azevedo-Junior SM, Telino-Júnior WR (2013b) Morcegos (Chiroptera) do Estado da Paraíba, nordeste do Brasil: distribuição e disponibilidade de material testemunho em coleções com base em trabalhos publicados e citações na chamada "literatura cinza". Revista Brasileira de Zoociências 15(1, 2, 3): 27-68.

Lobova TA, Geiselman CK, Mori SA (2009) Seed Dispersal by Bats in the Neotropics. The New York Botanical Garden Press, New York, 471 pp.

Marinho-Filho JS, Reis ML (2007) Relatório final do Levantamento e Monitoramento da Herpetofauna, Avifauna e Mastofauna da Usina Hidrelétrica de Boa Esperança. CHESF, Recife, 173 pp. 
Marques E, Ferrari SF, Beltrão-Mendes R, Bitencurti DP, Carvalho TM (2017) Mapeamento e caracterização dos fragmentos florestais na bacia hidrográfica do baixo rio São Francisco, Sergipe. Revista Geográfica Acadêmica 11(1): 104-128.

Marques JT, Pereira MJR, Marques TA, Santos CD, Santana J, Beja P, Palmeirim JM (2013) Optimizing sampling design to deal with mist-net avoidance in Amazonian birds and bats. PLoS One 8(9): e74505. https://doi.org/10.1371/journal.pone.0074505

Mikalauskas JS (2005) Morcegos. In: Carvalho CM,Vilar JC (Eds) Parque Nacional Serra de Itabaiana: Levantamento da Biota. IBAMA, Biologia Geral e Experimental, UFS, Aracaju, 93-103.

Mikalauskas JS, Rocha PA, Dias D, Peracchi AL (2014) Update on the distribution of Peropteryx leucoptera Peters, 1867 (Mammalia, Chiroptera, Emballonuridae): First record for the state of Sergipe, northeastern Brazil. Check List 10(2): 402-406. https://doi.org/10.15560/10.2.402

Mittermeier RA, Robles-Gil P, Hoffman M, Pilgrim J, Brooks T, Mittermeier CG, Lamoreu J, Fonseca GAB (2004) Hotspots revisited: Earth's biologically richest and most endangered terrestrial ecoregions. CEMEX/Agrupación Sierra Madre, Mexico City.

Muylaert RL, Stevens RD, Esbérard CE, Mello MA, Garbino GS, Varzinczak LH, Faria D, Weber MM, Rogeri PK, Regolin AL, Oliveira HFM, Costa LM, Barros MAS, SabinoSantos Jr G, Morais MAC, Kavagutti VS, Passos FC, Marjakangas EL, Maia FGM, Ribeiro MC, Galetti M (2017) ATLANTIC BATS: A data set of bat communities from the Atlantic Forests of South America. Ecology 98(12): 3227-3227. https://doi. org/10.1002/ecy.2007

Muylaert RL, Vancine MH, Bernardo R, Oshima JEF, Sobral-Souza T, Tonetti VR, Niebuhr BB, Ribeiro MC (2018) Uma nota sobre os limites territoriais da Mata Atlântica. Oecologia Australis 223(03): 302-311. https://doi.org/10.4257/oeco.2018.2203.09

Nogueira MR, Lima IP, Garbino GST, Moratelli R, Tavares VC, Gregorin R, Peracchi AL (2018) Updated checklist of Brazilian bats: version 2018. Comitê da Lista de Morcegos do Brasil - CLMB. Sociedade Brasileira para o Estudo de Quirópteros (Sbeq). http://www.sbeq.net/updatelist

Paglia AP, Fonseca GAB, Rylands AB, Herrmann G, Aguiar LMS, Chiarello AG, Leite YLR, Costa LP SicilianoS, Kierulff MCM, Mendes SL, Tavares VC, Mittermeier RA, Patton JL (2012) Lista Anotada dos Mamíferos do Brasil / Annotated Checklist of Brazilian Mammals. 2 ${ }^{\text {a }}$ Edição / $2^{\text {nd }}$ Edition. Occasional Papers in Conservation Biology, $n^{\circ} 6$. Conservation International, Arlington, $76 \mathrm{pp}$.

Pech-Canche JM, Estrella E, López-Castillo DL, Hernández-Betancourt SF, Moreno CE (2011) Complementarity and efficiency of bat capture methods in a lowland tropical dry forest of Yucatán, Mexico. Revista Mexicana de Biodiversidad 82(3): 896-903. https://doi.org/10.22201/ib.20078706e.2011.3.683

Pedroso MA (2018) Estrutura da taxocenose de morcegos (Chiroptera) do Médio Rio Madeira, Porto Velho, Rondônia: uma abordagem ecológica e metodológica. Master Dissertation, Universidade Federal de Sergipe, Sergipe, 93 pp.

Peracchi AL, Albuquerque ST (1993) Quirópteros do município de Linhares, Estado do Espírito Santo, Brasil (Mammalia, Chiroptera). Revista Brasileira de Biologia 53(4): 575-581.

Peracchi AL, Lima IP, Reis NR, Nogueira MR, Filho HO (2011) Ordem Chiroptera. In: Reis NR, Peracchi AL, Pedro WA, Lima IP (Eds) Mamíferos do Brasil, 2ª ed. Londrina, 155-234. 
Percequillo A, Santos K, Campos B, Santos R, Toledo G, Langguth A (2007) Mamíferos dos remanescentes florestais de João Pessoa, Paraíba. Biologia Geral e Experimental 7(2): 17-31.

Piccinini RS (1974) Lista provisória dos quirópteros da coleção do Museu Paraense Emílio Goeldi (Chiroptera). Boletim do Museu Paraense Emílio Goeldi, Zoologia 77: 1-32.

Reis NRD, Peracchi AL, Pedro WA, Lima IP (2007) Morcegos do Brasil, Univesidade Estadual de Londrina, Londrina, 253 pp.

Ribeiro MC, Metzger JP, Martensen AC, Ponzoni FJ, Hirota MM (2009) The Brazilian Atlantic Forest: How much is left, and how is the remaining forest distributed? Implications for conservation. Biological Conservation 142(6): 1141-1153. https://doi.org/10.1016/j. biocon.2009.02.021

Rocha PA, Mikalauskas JS, Gouveia SF, Silveira VVB, Peracchi AL (2010) Bats (Mammalia, Chiroptera) captured at the campus of the Federal University of Sergipe, including eight new records for the state. Biota Neotropica 10(3): 184-188. https://doi.org/10.1590/ S1676-06032010000300021

Rocha PA, Ruiz-Esparza J, Beltrão-Mendes R, Moura VS, Albuquerque N, Terra RFC, Mendonça LMC, Silvestre SM, Ferrari SF (2017a) Rapid surveys as a key tool for the inventory of the bat fauna of Brazil: New records for the coastal restinga. Neotropical Biology and Conservation 12(2): 19-29. https://doi.org/10.4013/nbc.2017.122.02

Rocha PA, Soares F, Dias D, Mikalauskas J, Feijó A, Vilar E, Daher MRM (2017b) New records of Micronycteris schmidtorum Sanborn, 1935 (PHYLLOSTOMIDAE, CHIROPTERA) for northeastern Brazil. Mastozoología Neotropical 24: 20-24.

Rocha PA, Tavares VC, Pedroso MA, Beltrão-Mendes R, Ruiz-Esparza J, Ferrari SF (2018) First record of Dermanura anderseni (Chiroptera, Phyllostomidae) for the Atlantic Forest. Mammalia 82(4): 388-392. https://doi.org/10.1515/mammalia-2017-0034

Ruschi A (1954) Algumas especies zoológicas e botânicas em vias de extinção no estado do Espírito Santo. Boletim do Museu de Biologia Prof. Mello Leitão (Serie Proteção de Natureza A) 16: 1-45.

Sampaio EM, Kalko EK, Bernard E, Rodríguez-Herrera B, Handley CO (2003) A biodiversity assessment of bats (Chiroptera) in a tropical lowland rainforest of Central Amazonia, including methodological and conservation considerations. Studies on Neotropical Fauna and Environment 38(1): 17-31. https://doi.org/10.1076/snfe.38.1.17.14035

Santos AL, Carvalho CM, Carvalho TM (2013) Importância de remanescentes florestais para conservação da biodiversidade: Estudo de caso na Mata Atlântica em Sergipe através de sensoriamento remoto. Revista Geográfica Acadêmica 7(2): 58-84. https:// doi.org/10.18227/1678-7226rga.v7i2.2992

Silva CR, Bernard E (2017) Bioacoustics as an important complementary tool in bat inventories in the Caatinga drylands of Brazil. Acta Chiropterologica 19(2): 409-418. https:// doi.org/10.3161/15081109ACC2017.19.2.017

Silva LAM, Marinho-Filho J (2010) Novos registros de morcegos (Mammalia: Chiroptera) na caatinga de Pernambuco, nordeste do Brasil. Revista Nordestina de Zoologia 4: 70-78.

Simmons NB (2005) Order Chiroptera. Mammal Species of the world: a taxonomic and geographic reference 1: 312-529. 
Simmons NB, Voss RS (1998) The mammals of Paracou, French Guiana, a Neotropical lowland rainforest fauna. Part 1, Bats. Bulletin of the American Museum of Natural History. 237:1-219.

Soares FAM, Rocha PA, Mikalauskas JS, Graciolli G, Ferrari SF (2017) Ectoparasitic bat flies (Diptera, Streblidae) of bats (Chiroptera, Mammalia) from Mata do Junco Wildlife Refuge, Sergipe, Northeastern Brazil. Oecologia Australis 21(4): 385-395. https://doi. org/10.4257/oeco.2017.2104.03

Sousa MAN, Langguth A, Gimenez EA (2004) Mamíferos de Brejos de Altitude da Paraíba e Pernambuco. In: Porto K, Cabral JJP, Tabarelli M (Eds) Brejos de altitude: história natural, ecologia e conservação. Ministério do Meio Ambiente, Brasília, 229-254.

Straube FC, Bianconi GV (2002) Sobre a grandeza e a unidade utilizada para estimar esforço de captura com utilização de redes de neblina. Chiroptera Neotropical 8(1-2): 150-152. Tavares VC, Gregorin R, Peracchi AL (2008) Diversidade de morcegos no Brasil: lista atualizada com comentários sobre distribuição e taxonomia. In: Pacheco SM, MarquesRV, Esberard CEL (Eds) Morcegos no Brasil: biologia, sistemática, ecologia e conservação. Armazém Digital, Porto Alegre, 25-58.

Varjabedian R (2010) Lei da Mata atlântica: Retrocesso ambiental. Estudos Avançados 24(68): 147-160. https://doi.org/10.1590/S0103-40142010000100013

Varzinczak LH, Bernardi IP, Passos FC (2015) Is the knowledge of bat distribution in the Atlantic Rainforest sufficient? Comments about new findings and a case study in the Paraná State coastal area, Brazil. Mammalia 80: 263-269. https://doi.org/10.1515/ mammalia-2014-0130

Willig MR (1983) Composition, microgeographic variation and sexual dimorphism in Caatingas and Cerrado bat comunities from northeastern Brazil. Bulletin of Carnegie Museum of Natural History. Pittsburgh 23: 1-131.

\section{Appendix I}

Examined material: Artibeus lituratus (LBC 0088); Micronycteris microtis (LBC 0089; LBC 0090); Dermanura cinerea (LBC 0091; LBC 0092; LBC0093); Carollia perspicillata (LBC 0094; LBC 0095; LBC0096; LBC 0097); Platyrrhinus lineatus (LBC0098); Sturnira lilium (LBC0099; LBC0100; LBC0101); Trachops cirrhosus (LBC 0102); Artibeus planirostris (LBC0103); Artibeus obscurus (LBC 0104); Glossophaga soricina (LBC0105; LBC 0106; LBC 0107); Molossus molossus (LBC 0108); Myotis lavali (LBC 0109); Myotis riparius (LBC 0110); Peropteryx macrotis (LBC 0111); Peropteryx leucoptera (LBC 0112; LBC 0113); Lophostoma brasiliense (LBC 0114); Desmodus rotundus (LBC 0115); Phyllostomus discolors (LBC 0116); Phyllostomus hastatus (LBC 0117); Micronycteris minuta (LBC 0118); Lasiurus blossevillii (LBC 0119); Platyrrhinus recifinus (LBC 0120; LBC 121); Tonatia saurophila (LBC 122). 